ПИТАННЯ МЕТОДОЯОГІї

(ЛОКАЯЬНІ КОНТЕКСТИ ГЛОБАЯЬНИХ ФІЛОСОФІЙ)

\author{
Ruta Marija Vabalaite
}

\title{
BETWEEN LOCALITY AND GLOBALITY: THE PROBLEMS OF THE HISTORY OF PHILOSOPHY IN LITHUANIA
}

\section{Introduction}

Lithuanian tradition of philosophy has a quite long history, starting with the studies of noblemen in oldest European universities, continuing with the establishment of higher schools in its one territory, receptions of European philosophical heritage and an effort to contribute to its ongoing development. Nevertheless, there are some open questions related to the meaning of the very concept of Lithuanian philosophy, evaluation of its scope and setting its periods. Considering the small number of present-day Lithuanian authors and their readers, the problem of the local and global significance of Lithuanian philosophy reveals itself to be rather complex. Thus the research project "The Local Contexts of Global Philosophies” is particularly relevant for an apprehending and evaluating our national philosophical tradition, clarifying the activities of scholars, who "have made a notable contribution to the development of philosophy [...] through the assimilation and rethinking of global philosophical discussions” [Yosypenko, Khoma 2020: 6].

\section{Problems and questions}

When examining history, the first question that arises is who should be considered Lithuanian philosophers. As it is well known the concept of nation has changed throughout history, thus it had to be considered that up to the last centuries it included all the citizens of a State - the citizens of the former Grand Duchy of Lithuania in our case. The attributes "Lituanus" and "Litwyn" do not necessarily mean knowing the Lithuanian language, all the more philosophical thinking and its description in this language. Consequently, there exists a controversy whether to cover all philosophical works written in the territories of historical Lithuania or to include only the works of ethnic Lithuanians (or at least the works written in the Lithuanian language). The answer to this question influences an apprehension of the relevant sources of the history of philosophy in Lithuania. The upholders of ethnic perspective tend to include not only philosophical works in the literal sense of the word but also the texts in which at least some philosophical content might be detected. The reason that is given in this

(C) R. M. Vabalaite, 2021 
case consists in the importance of the text for the development of Lithuanian self-awareness or its social significance. A considerable part of philosophers does not accept this position, they do not "overestimate ethnical background of the philosophers" [Viliūnas 2014: 324] and accordingly prioritise the professionalism of philosophical thought in place of it. The complexity shows itself yet more if we estimate the impact of philosophical works on Lithuanian culture. Greater local significance was achieved by the authors rightly called "moralizing writers" or "didactic writers" [Plečkaitis 2004: 728], who wrote historical, public, fictional texts, focused on moral and political issues. These works might be included in the history of philosophical thought in Lithuania as some phenomena of practical philosophy, but they make no impact on global philosophy.

Nowadays these controversies include an old question of the aim of philosophy written in Lithuanian or written by Lithuanians notwithstanding. Is philosophy a means for achieving social welfare understood in a narrow view? Or is it still the endeavour at knowledge for its own sake? The best solution might be a conclusion that the true professionals of philosophy meeting the global standards of doing it should occasionally provide their insights into more or less local social issues. In fact, specializing in actual contemporary problems of practical life quite often results in arguing for a solution that is adopted beforehand or in spreading the "correct" ideology. The "topical” themes render a higher probability of successful engagement in global projects but it is questionable whether the grants of global foundations necessarily mean the highest strength of philosophical thought and coincide with it.

The above-mentioned empirical problems might be considered as acquiring some philosophical meaning if conceived in the context of Martin Heidegger's and Hans-Georg Gadamer's thought about the philosophical language and its understanding. If we adhere to the ideas that "where the translation is necessary, the gap between the spirit of the original words and that of their reproduction must be taken into account. It is a gap that can never be completely closed"; "substantive understanding of foreign language means thinking in it"; and "every translation that takes its task seriously is at once clearer and flatter than the original. Even if it is a masterly re-creation, it must lack some of the overtones that vibrate in the original" [Gadamer 2006: 386-387, 388] we need to give priority to philosophy written in the national language.

On the other hand, we have to consider the specificity of the philosophical language, acquisition of which forces appeal to the translations or explanations of the global heritage of philosophy. The issue seems to be not so profound taking into account multilingual persons who are dedicated to philosophy. Their understanding of the world depending on a couple of languages that they think in might prompt significant insights.

Actually, there was a period of multi-ethnic and multilingual culture in Lithuanian history and the spread of philosophy coincided with it. Thus, let us proceed further with describing the works and the authors related to Lithuania and at the same time relevant to the philosophy of Europe, or at least neighbouring countries.

\section{The most prominent period and the most famous philosopher}

It might be claimed that the professional philosophy commenced in Lithuania as a global phenomenon. According to the best-known historian of Lithuanian philosophy Romanas Plečkaitis (1933-2009), it appeared at 1507 as a subject in the curriculum of Vilnius higher 
school (schola particularis) that provided education for Dominican monks ${ }^{1}$. Unfortunately, there are neither books nor lecture notes discovered from that time, but it is quite clear that monks were thought Thomistic philosophy, which was prevalent in all European educational institutions. It is established that one of the school's professors graduated from Salamanca and it can be presumed that others were graduates of a little less known European academic institutions of the time.

A later but not less important stage in the spread of professional philosophy in Lithuania started with the establishment of Königsberg University (Albertina) in Eastern Prussia (1544), as enduring cultural relations of West Lithuania with Eastern Prussia inter alia manifested through the Lithuanian youth education at this old and respected institution. The global nature of the University is evident if one notices that the professor, who was invited to take up the post of first Vice-Rector, had previously studied in the universities of Cracow, Leuven, Wittenberg, Leipzig and Siena ${ }^{2}$.

In a few decades, the Latin scholastic tradition was amplified by Jesuits, who founded Vilnius Academy (1570) - the first institution of higher learning available for non-clergy. Another significant step in the development of philosophy was a transformation of this college into a higher school, named Vilnius Academy and University of the Society of Jesus (1579), which provided three-year course studies at the Faculty of Philosophy.

In the meantime, Vilnius became a centre of discussions between Catholic professors and Protestant reformers. It is maintained that "there was no citizen who was not interested in theology and philosophy” [Jurginis 1965: 221]. Counter-Reformation adherents, Lutherans, Calvinists, Arians and Socinians held debates regarding basic conceptions of the divine, moral precepts, interpretations of biblical and medieval authors ${ }^{3}$. The reformation was a significant phenomenon of philosophical thought due to ideas of natural law, social contract, tolerance and employment of philosophical rationalism.

However, the prevailing opinion is that the Protestant Reformers influenced academic life not so much with their own positive activities as with what they, "as a positive opposition, induce to create" [Lukšaitè 1994: 15]. Vilnius University was not far behind similar Central European universities due to the creative tensions created by the interaction between both sides of Christian thinkers. These were the times when Martinus Smiglecius (1562/64$1618)^{4}$ - the most famous philosopher of Vilnius University worked (actually he remains in that honourable position yet to this day). His Latin treatise on Logics was issued at Ingolstadt in 1618, and then, "became an influential textbook especially in England, where it went through three editions from 1634 to 1658 , even giving rise to a circle of "Smiglecians"”

${ }^{1}$ Ukrainian readers might draw their attention to the fact that establishing an analogous school in Lviv was intended in the same document.

${ }^{2}$ Hither it is important to mention that after obtaining his academic degrees and returning to Lithuania, the said scholar - Abraham Kulvietis (1509-1545) established Vilnius grammar school where the seven liberal arts were taught in the spirit of Protestantism. Unfortunately the archives of the school are lost and one might only guess about the philosophical ideas talked over in it.

${ }^{3}$ Furthermore, it is worth noting that one of these thinkers - Szymon Budny ( 1530-1593), whose exact origin is unfortunately unknown (a part of historians agree that he was born in Poland, others emphasise a high probability that he was Belarusian), published a book which aimed to introduce the ideas of Reformation to Russian-speaking people of the Grand Duchy of Lithuania, including (among others) Ukrainians [Jurginis 1965: 224; Lukšaitè 2017: 112].

${ }^{4}$ Readers of the journal might be interested in his relationship with Ukraine, so it can be noticed that he was born in Lviv and started studying at the Cathedral school in his native city [Plečkaitis 2004: 698], thus his work might be considered as a segment of the Ukrainian history of philosophy. 
[Novotný 2013: 19; Roncaglia 1995: 31]. Moreover, the established historian of Lithuanian scholastic philosophy points up, that this textbook was known by the Sorbonne philosophers and by German Protestant thinkers and was of particular influence in Lithuania for the whole century [Plečkaitis 1979: 29]. What were the peculiarities of this famed book? Obviously, Smiglecius mostly relied on Thomistic interpretation of Aristotelian logics, though included the theories by other antique and medieval philosophers. Even the leaders of the Jesuit order in Rome discussed his work twice, but the appointed reviewers both times condemned it "as being too independent” [Plečkaitis 2004: 268] ${ }^{5}$. He acknowledged the existence of universals both in things and in mind, giving the priority to essences as lying in the nature of things and then existing only by instantiations in them and in our experiences of commonalities. By now, there is a lack of consensus among the researchers in their opinions on Smiglecius' theory attribution to any variant of scholastic realism or nominalism. According to previous opinions it might be considered as moderate realism, but recent estimation argues that it "would rather be regarded as an intermediate model between moderate realism and conceptualism, which connected particular elements of both the above-mentioned trends" [Valatka 2009: 174]. The historians of philosophy appreciate Smiglecius' insight into the elements of scientific inquiry, his handling of the problems of semantics and his thought on fictions and impossible entities.

\section{Experts in German classical philosophy and their influence}

The next philosopher, known not only in Eastern Europe - Johann Heinrich Abicht (1762-1816), worked in Lithuania only after a couple of centuries. He relocated from Erlangen University as an already known adherent of Immanuel Kant and Karl Leonhard Reinhold. By that time, he had published 24 books and many articles in the German publications and had been honoured by the Royal Prussian Academy of Sciences award for the answer to the question: "What real progress has metaphysics made in Germany since the time of Leibniz and Wolff?” [Putinaite 2004: 188-189]. Therefore, it is evident that his theory was familiar at least to the philosophers of German-speaking countries. On the other hand, historians tell that due to his intricate thought and obscure style he was "surnamed German Hera-

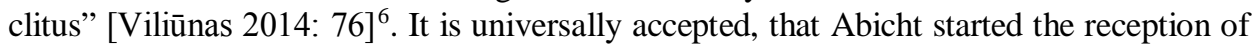
Kant's system of transcendental philosophy and the other classic German philosophical theories in Lithuania. His best-known treatise was his report addressed to the community of Vilnius University and entitled "On the limits of experience", where he explained his Kantian views of two necessary poles of human knowledge employing the Baconian metaphor of ways to achieve true knowledge [Abichtas 1978: 89]. The difference from Kant consisted in the concept of the source of an a priori side of the experience. Seeking to bypass sceptical arguments Abicht presupposed a primary experience of the spiritual core as a basis of human existence and considered the primary spirituality as a clarification of his assumption of innate ideas and innate principles of cognition. Unfortunately, Abicht was the last philosopher who

${ }^{5}$ Eventually, Smiglecius obtained approval for publication from the delegate of the Jesuit order for Poland [Roncaglia 1995: 31; Plečkaitis 2004: 268].

${ }^{6}$ Perhaps because of that Lithuanian scholars had started the research with attempts to delineate the aspect of practical philosophy in his treatises [Tunaitis 1974: 19-24, Tunaitis 1980: 19-33]. Still most successful description of all his philosophical work has been written by the same author as a part of his article on "The development of Kantianism" [Tunaitis 2008: 50-58]. Meanwhile, other historians only sketch the general structure of his last book that was published in Vilnius, thus our history of philosophy still lacks thorough research into the grounds of Abicht's philosophy as a whole. 
delivered lectures in Latin and whose thought was known wider than in one State. The academic authorities had claimed to teach in Polish and so the possibilities to choose famous professors have narrowed. Meanwhile, the quality of studies had to be ensured by providing possibilities for chosen lecturers to do internships at universities abroad.

That time the intention was to strengthen the reception of the philosophy of the so-called Scottish school of "common sense", but the winner of the contest for the seat of professor of philosophy at Vilnius University in 1821 - Józef Gołuchowski $(1797$ - 1858) had disobeyed authorities' mind and chose to deepen his knowledge of German philosophy. Likewise the aforesaid philosophers, Gołuchowski was not related with historical Lithuanian lands in his student's years ${ }^{7}$, he got his first academic degrees in Wien and Warsaw, then continued studies in Heidelberg and Erlangen. During the internship, he attended the courses of Georg Wilhelm Friedrich Hegel and Friedrich Wilhelm Joseph von Schelling, wrote and published a study "The Role of the Philosophy in the Life of Entire Nations and Separate Individuals" (1822). The study was not important in the context of German philosophy; nevertheless, it made a huge influence on philosophical thought in the Russian Empire of that time. For the citizens of historical lands of the Republic of the Two Nations, it became an inauguration of Polish philosophical romanticism, and for Russians, it became the first introduction to Schelling's philosophy ${ }^{8}$, although Schelling's influence on the above-mentioned study may be noticed only if Schellingian ideas are known beforehand ${ }^{9}$. However, it might be evaluated as the first book in the field of popularization of philosophy and even popularization of the national one ${ }^{10}$. The real introduction into classical German philosophy was written by Gołuchowski at the end of his life, already outside the university, in his book "The Considerations on the Main Tasks in the Life of a Person" $(1861)^{11}$. For this book and highly successful lectures at Vilnius University, he should be considered a pioneer of the reception of Schelling's and Hegel's philosophies in Lithuania.

\section{The scholar of global fame and not yet studied by Lithuanian philosophers}

The last but not least question is about the philosophical tradition of Jews historically related to Lithuania or using their own terms - Litvaks and Lita. For a long time, Lithuanian philosophy historians did not inquire into the thought of arguably the most famous Vilnius citizen - Elijah ben Solomon Zalman (1720-1797), commonly referred to as Vilna Gaon or Elijah of Vilna ${ }^{12}$. Surely, the question of his relationship with philosophical thought and with

${ }^{7}$ He was born in the village Łączki Kucharskie in Galicia - the historical land of Ukraine, which was a part of the Austro-Hungarian Empire at that date.

${ }^{8}$ Russian translation of the treatise was published in Saint Petersburg in 1834, but unfortunately, it does not meet the current standards for translations, as the translator and the author of an introduction academician Danilo Michailovic Vellanskij (1774-1847) made omissions and changes. He explained the great necessity of the book as readers' need to become acquainted with moral ideas of Schelling's transcendental philosophy [Велланский 1834: IX].

${ }^{9}$ For more on this, see my article "The Concept of the Purpose of Philosophy in the Tractates of Józef Gołuchowski” [Vabalaitè 2021: 21-25].

10 Goluchowski wrote in a Hegelian manner about philosophy as the highest form of national consciousness that springs from the deepest sources underlying within the national spirit and called the true philosopher "a pure consciousness of his nation" [Gołuchowski 1822: 102].

${ }^{11}$ The chapter of the book was an explanation of the need to present the latest German philosophy for the Slavic readers in a special way [Gołuchowski 1861: 43-52].

${ }^{12}$ His manuscripts had not even been included in volumes of the academic edition "Sources of History of Philosophical thought in Lithuania”, published in 1980 and later on. 
Lithuanian culture is a hard one ${ }^{13}$. Nevertheless, it is worth pointing to the recent researches published by Aušra Pažèraite - Lithuanian scholar in the field of Jewish ethical ideas. She notes the assumption that due to Elijah's huge erudition he was also acquainted with European philosophers, perhaps even with the philosophy of Immanuel Kant, and explains that "such suspicion may be raised by the introductory paragraphs of his commentary on the Book of Proverbs, in which he distinguishes between theoretical and practical reason” [Pažeraitė 2019: 22]. Due to Pažèraite's researches of Lithuanian Jewish religious ethics, the historians of philosophy might expand their understanding of the intellectual context of local philosophical thought; to engage in discussion of the relation of philosophical and theological ideas in Litvak's teachings of Judaism; to approach a question of an influence of Mithnaggedism ${ }^{14}$, which is based on an analytic and rationalistic study of Thorah for its own sake [Lvov, Pažèraite 2020: 187-188], to its adherents' apprehension of the ideas of global philosophy.

\section{Conclusions}

In conclusion, we might recognize that in the initial epoch philosophy in Lithuania did not differ from philosophical teaching in West European academic institutions. Discussed philosophers were as good as known thinkers of other Central and Eastern European countries, but neither of them wrote in Lithuanian. Considering this, we need to think over the more efficient ways to enrich the local tradition of philosophy. What is more important: either striving to original philosophical theories or seeking to get whole advantage of the already globally or at least regionally recognized works? Anyway, it is worth concentrate the efforts on the translations of the heritage of philosophy, which had been created in Lithuania and had proved its importance even outside the Lithuanian borders. This is particularly relevant if we think that understanding philosophical tradition means partaking in it.

\section{СПИСОК ЛІТЕРАТУРИ}

Велланский, Д. М. (1834). Предуведомление от издателя. In Голуховский, I. Философия, относящаяся к жизни целых народов и каждого человека (pp. I-X). Санкт-Петербург: Типография Штаба отдельного корпуса внутренней стражи.

Йосипенко, С., Хома, О. (2020). Локальні контексти глобальних філософій. Sententiae, 39(2), 6-7. https://doi.org/10.31649/sent39.02.006

Abichtas, J. H. (1978). Apie patyrimo ribas. Problemos, 22(2), 89-93. https://doi.org/10.15388/ Problemos.1978.22.6235

Gadamer, H.-G. (2006). Truth and Method. London, New York: Continuum.

Gołuchowski, J. (1822). Die Philosophie in ihrem Verhältnisse zum Leben ganzer Völker und einzelner Menschen. Erlangen: J.J. Palm und E. Enke.

Jurginis, J. (1965). Renesansas ir humanizmas Lietuvoje. Vilnius: Vaga.

Kundrotas, V. (2020). Humanizmas ir renesansas: Lietuvos ir Europos moksliniu ir kultūriniu santykiu raida. Vilnius: Baltijos kopija.

${ }^{13}$ The historians point to the sad and nowadays hardly conceivable events when the Great Synagogue "was attacked and burned three times by the students of the Jesuit academy and their willing accomplices" [Roskies 2017].

${ }^{14}$ Or Misnagdim - the name for Eastern European Jewish movement enhanced by Elijah of Vilna and opposed to Chasidism. 
Lukšaite, I. (1994). XVI-XVII a. reformacijos Lietuvoje reikšmė: naujoviu keliai. In I. Lukšaitė (Ed.), Protestantizmas Lietuvoje: istorija ir dabartis (pp. 7-17). Vilnius: Apyaušris.

Lukšaitè, I. (2017). Kai tikejjimas keitè pasauli.... Reformacija Lietuvoje. Vilnius: Mokslo ir enciklopediju leidybos centras.

Lvov, A., \& Pažèraite, A. (2020). Religinio žmogaus atsakomybė: Lietuvos žydų rabiniška mintis tarp racionalizmo ir chasidiško misticizmo. Vilnius: Vilniaus universiteto leidykla.

Mikelaitis, G. (Ed.). (1996). Lietuvos filosofine mintis: chrestomatija. Vilnius: Aidai.

Novotný, D. D. (2013). Ens Rationis from Suarez to Caramuel: A Study in Scholasticism of the Baroque Era. New York: Fordham University Press.

Pažèraitė A. (2019). Nesuk $i ̣$ keliq iš takelio: Lietuvos žydu religinès ir filosofinès minties paveldo trajektorijomis. Vilnius: Vilniaus universiteto leidykla.

Plečkaitis, R. (Ed.). (1979). Filosofija Vilniaus universitete 1579-1832. Vilnius: Mintis.

Plečkaitis, R. (Ed.). (1980). Lietuvos filosofinès minties istorijos šaltiniai I tomas. Vilnius: Vaga.

Plečkaitis, R. (2004). Lietuvos filosofijos istorija I tomas. Viduramžiai - Renesansas - Naujieji amžiai. Vilnius: Kultūros, filosofijos ir meno institutas.

Putinaite, N. (2004). Paskutinioji proto revoliucija: Kanto praktinès filosofijos studija. Vilnius: KFMI, Aidai.

Roncaglia, G. (1995). Smiglecius on entia rationis. Vivarium, 33(1), 27-49. https://doi.org/10.1163/ 1568534952579795

Roskies, D. G. (2017). Isimylëję litvakai. https://judaikostyrimucentras.com/2017/10/02/isimylejelitvakai/

Tunaitis, S. (1974). Kantiškoji tradicija J. H. Abichto etikoje. Problemos 14, 19-24. https://doi.org/ 10.15388/Problemos.1974.14.5553

Tunaitis, S. (1980). Abichtas Johanas Heinrichas. In Plečkaitis, R. (Ed.), Lietuvos filosofinès minties istorijos šaltiniai I tomas (pp. 19-33). Vilnius: Vaga.

Tunaitis, S. (2008). Kantizmo sklaida. In D. Viliūnas (Ed.), Apšvietos ir romantizmo kryžkelèse. Filosofijos kryptys ir kontroversijos Lietuvoje XVIII a. pabaigoje - pirmojoje XIX a. pusejje (pp. 35-63). Vilnius: KFMI.

Vabalaitè, R. M. (2021). Filosofijos paskirties samprata Juozapo Goluchovskio traktatuose. Logos, 106, 21-25. https://doi.org/10.24101/logos.2021.03

Valatka, V. (2009). The History of Logic in Lithuania: the Theory of Universals in the 16th Century. Filosofija. Sociologija, 20(3), 173-181. http://mokslozurnalai.Imaleidykla.lt/filosofijasociologija/ 2009/3/5636

Viliūnas, D. (2014). Filosofija Vilniuje XIX amžiaus pirmoje pusèje. Vilnius: LKTI leidykla.

Одержано 12.02.2021

\section{REFERENCES}

Abichtas, J. H. (1978). Apie patyrimo ribas. Problemos, 22(2), 89-93. https://doi.org/10.15388/ Problemos.1978.22.6235

Gadamer, H.-G. (2006). Truth and Method. London, New York: Continuum.

Gołuchowski, J. (1822). Die Philosophie in ihrem Verhältnisse zum Leben ganzer Völker und einzelner Menschen. Erlangen: J.J. Palm und E. Enke.

Jurginis, J. (1965). Renesansas ir humanizmas Lietuvoje. Vilnius: Vaga.

Kundrotas, V. (2020). Humanizmas ir renesansas: Lietuvos ir Europos moksliniu ir kultūriniu santykiu raida. Vilnius: Baltijos kopija.

Lukšaitè, I. (1994). XVI-XVII a. reformacijos Lietuvoje reikšmė: naujovių keliai. In I. Lukšaite (Ed.), Protestantizmas Lietuvoje: istorija ir dabartis (pp. 7-17). Vilnius: Apyaušris.

Lukšaitè, I. (2017). Kai tikejjimas keitè pasauli.... Reformacija Lietuvoje. Vilnius: Mokslo ir enciklopediju leidybos centras.

Lvov, A., \& Pažėraite, A. (2020). Religinio žmogaus atsakomybė: Lietuvos žydų rabiniška mintis tarp racionalizmo ir chasidiško misticizmo. Vilnius: Vilniaus universiteto leidykla.

Mikelaitis, G. (Ed.). (1996). Lietuvos filosofine mintis: chrestomatija. Vilnius: Aidai. 
Novotný, D. D. (2013). Ens Rationis from Suarez to Caramuel: A Study in Scholasticism of the Baroque Era. New York: Fordham University Press.

Pažèraitè A. (2019). Nesuk $i$ kelia iš takelio: Lietuvos žydu religinès ir filosofinès minties paveldo trajektorijomis. Vilnius: Vilniaus universiteto leidykla.

Plečkaitis, R. (2004). Lietuvos filosofijos istorija I tomas. Viduramžiai - Renesansas - Naujieji amžiai. Vilnius: Kultūros, filosofijos ir meno institutas.

Plečkaitis, R. (Ed.). (1979). Filosofija Vilniaus universitete 1579-1832. Vilnius: Mintis.

Plečkaitis, R. (Ed.). (1980). Lietuvos filosofinès minties istorijos šaltiniai I tomas. Vilnius: Vaga.

Putinaite, N. (2004). Paskutinioji proto revoliucija: Kanto praktines filosofijos studija. Vilnius: KFMI, Aidai.

Roncaglia, G. (1995). Smiglecius on entia rationis. Vivarium, 33(1), 27-49. https://doi.org/10.1163/ 1568534952579795

Roskies, D. G. (2017). Isimylëję litvakai. https://judaikostyrimucentras.com/2017/10/02/isimylejelitvakai/

Tunaitis, S. (1974). Kantiškoji tradicija J. H. Abichto etikoje. Problemos 14, 19-24. https://doi.org/ 10.15388/Problemos.1974.14.5553

Tunaitis, S. (1980). Abichtas Johanas Heinrichas. In Plečkaitis, R. (Ed.), Lietuvos filosofinès minties istorijos šaltiniai I tomas (pp. 19-33). Vilnius: Vaga.

Tunaitis, S. (2008). Kantizmo sklaida. In D. Viliūnas (Ed.), Apšvietos ir romantizmo kryžkelèse. Filosofijos kryptys ir kontroversijos Lietuvoje XVIII a. pabaigoje - pirmojoje XIX a. pusèje (pp. 35-63). Vilnius: KFMI.

Vabalaite, R. M. (2021). Filosofijos paskirties samprata Juozapo Goluchovskio traktatuose. Logos, 106, 21-25. https://doi.org/10.24101/logos.2021.03

Valatka, V. (2009). The History of Logic in Lithuania: the Theory of Universals in the 16th Century. Filosofija. Sociologija, 20(3), 173-181. http://mokslozurnalai.lmaleidykla.lt/filosofijasociologija/2009/3/5636

Viliūnas, D. (2014). Filosofija Vilniuje XIX amžiaus pirmoje pusëje. Vilnius: LKTI leidykla.

Vellansky, D. M. (1834). Publisher's notice. [In Russian]. In I. Golukhovsky, Philosophy relating to the life of entire nations and each person (pp. i-x). [In Russian].St. Petersburg: Printing house of Headquarters of the Separate corps of internal guard.

Yosypenko, S., \& Khoma, O. (2020). Local Contexts of Global Philosophies. [In Ukrainian]. Sententiae, 39(2), 6-7. https://doi.org/10.31649/sent39.02.006

Received 12.02.2021

\section{Ruta Marija Vabalaite}

\section{Between Locality and Globality: The Problems of the History of Philosophy in Lithuania}

The article deals with the problem of the local and global significance of Lithuanian philosophy. We discuss questions related to the meaning of the very concept of Lithuanian philosophy and evaluation of its scope. A controversy whether to cover all philosophical works written in the territories of historical Lithuania or to include only the works of ethnic Lithuanians (or at least the works written in Lithuanian) is talked over. The problem of the priorities in determining the relevant sources of the history of philosophy in Lithuania is described by pointing to the complexity of an assessment as the importance of the text for the development of Lithuanian self-awareness or its social significance scarcely coincide with its impact on global philosophy. The question of the priority of the texts written in the national language versus the translations of the main heritage of Western philosophy is addressed. We proceed further with a description 
of the works and the authors related to Lithuania and at the same time relevant to the philosophy of Europe, or at least neighbouring countries. The characteristics of the creative opposition between Protestant and Counter-Reformation thinkers is given. Martinus Smiglecius book on Logics and the main figures in the reception of German classical philosophy are discussed. Finally, the philosophical aspects of Litvak Judaism and their research are referred to.

\section{Рута Марія Вабалайте}

\section{Між локальністю і глобальністю: проблеми історіі філософії в Литві}

У статті розглядається проблема локального та глобального значення литовської філософії. Ми обговорюємо питання сенсу самого поняття литовської філософії та оцінки його об’єму. Розглядається суперечка щодо того, охоплює воно всі філософські твори, написані на територіях історичної Литви, чи включає лише твори етнічних литовців (або принаймні твори, написані литовською мовою). Проблема пріоритетів у визначенні джерел, релевантних щодо історії філософії в Литві, описується через наголошення на складності оцінки, адже важливість тексту для розвитку самосвідомості литовців або його соціальна значущість майже не збігаються з його впливом на глобальну філософію. Розв'язується питання пріоритетності текстів, написаних національною мовою, щодо перекладів основної спадщини західної філософії. По тому продовжується опис творів і авторів, що мають відношення до Литви та водночас стосуються європейської філософії чи принаймні філософії сусідніх країн. Наведено характеристики творчої опозиції між мислителями-протестантами та представниками Контрреформації. Обговорюється книга Мартіна Сміглеція про логіку, а також основні постаті в рецепції німецької класичної філософії. Насамкінець, заторкнуто філософські аспекти литвакського юдаїзму та наявні дослідження зазначених аспектів.

Ruta Marija Vabalaite, Doctor of humanities in philosophy, assistant professor, Mykolas Romeris University (Vilnius, Lithuania).

Рута Марія Вабалайте, доктор філософських наук, доцент, Університет Миколи Ромеріса (Вільнюс, Литовська республіка).

e-mail:marijavabalaite@gmail.com 